\title{
Socio-technical systems analysis of waste to energy from municipal solid waste in developing economies: a case for Nigeria
}

\author{
Hope O. Iyamu*, Martin Anda, and Goen Ho \\ School of Engineering and Information Technology, Murdoch University, Western Australia, WA 6150, Australia
}

Received: 25 February 2017 / Received in final form: 1 July 2017 / Accepted: 27 July 2017

\begin{abstract}
Waste generation is an inevitable by-product of human activity, and it is on the rise due to rapid urbanisation, industrialisation, increased wealth and population. The composition of municipal solid waste (MSW) in developed and developing economies differ, especially with the organic fraction. Research shows that the food waste stream of MSW in developing countries is over $50 \%$. The case study for this investigation, Nigeria, has minimal formal recycling or resource recovery programs. The average composition of waste from previous research in the country is between 50-70\% putrescible and 30-50\% non-putrescible, presenting significant resource recovery potential in composting and biogas production. Waste-to-energy (WtE) is an important waste management solution that has been successfully implemented and operated in most developed economies. This contribution reports the conditions that would be of interest before WtE potentials of MSW is harnessed, in an efficient waste management process in a developing economy like Nigeria. The investigation presents a set of socio-technical parameters and transition strategy model that would inform a productive MSW management and resource recovery, in which WtE can be part of the solution. This model will find application in the understanding of the interactions between the socio-economic, technical and environmental system, to promote sustainable resource recovery programs in developing economies, among which is WtE.
\end{abstract}

\section{Introduction}

The increasing demand to reduce climate change impact of greenhouse gases (GHG), increasing demand for natural resources, expenditures and society expectations, has promoted the drive for renewable energy from different sources to replace fossil fuels, including municipal solid waste (MSW). The primary driver for solid waste related activities is the resource value. However, municipal solid waste management (MSWM) has become imperative for developing economies due to the problems caused by public health and the environment, and the benefits derived if properly managed. The International Solid Waste Association, investigated the amount of MSW disposed to dumpsites and sanitary landfills, worldwide, to be around 70\%. Also, an estimate of $11 \%$ is treated to thermal and waste to energy facilities, and $19 \%$ is recycled or treated to mechanical and biological treatment [1]. Although the benefits of MSW diversion from landfills and dumpsites are enormous, the implementation of this concept in developing economies is unsatisfactory due to different challenges that include sociotechnical and environmental management systems.

\footnotetext{
* e-mail: h.iyamu@murdoch.edu.au
}

Different organisations have demonstrated some of the benefits of waste diversion from landfills, and one of them is SUEZ, Australia. This group diverts approximately 887000 tonnes of waste, combined from all its various clients (governments and private businesses) across Australia, from landfill every year, and enables oil and gas sector to process resources sustainably and efficiently [2]. Also, it is interesting to note that 3 tonnes of municipal waste have as much energy as 1 tonne of fuel oil, in it. The WtE market is growing at an unprecedented rate, with reports showing growth from $\$ 19$ billion in 2012 to at least $\$ 29.2$ billion by $2022[3,4]$.

Other benefits from an effectively managed MSW in any economy include; increased quality of the environment and soil nutrient replenishment through composting. This study will focus on waste-to-energy (WtE), one of the salient benefits of MSWM but, only after waste minimisation, collection and recycling initiatives have been considered, and even then undermined and subdued by many factors, which include socio-economic, environmental and technical limitation.

WtE technology has seen tremendous changes and transitions since its introduction over a century ago . However, these changes have mainly been observed in the developed economies, while emerging economies have 
experienced insignificant transitional developments. This development is stirring curiosity on the level of waste management and its developmental process in low-income economies. Also, research has shown that the predominant MSW stream in many developing economies is the organic waste $[5,6]$ and substantial energy can potentially be generated through technological processes from municipal waste.

In this type of WtE system, the MSW is the feedstock for the generation of bioenergy. In Australia, between 2007 and 2008, bioenergy represented $78 \%$ of the country's renewable energy, electricity generation of 2 terawatthours (TWh), with a projected increase of $2.2 \%$ use increase per year [7].

Every year, one-third of the food produced in the world for human consumption is destroyed or wasted, and it is estimated to be 1.3 billion tonnes [8]. UK-based Waste \& Resources Action Program, claims that every tonne of food waste results in approximately 3.8 tonnes of GHG emissions. The decomposition of this organic fraction of MSW contributes to the emission of methane gas, $\mathrm{CH}_{4}$, a potent GHG [9]. A recent study reports that methane has a warming potential of 28-36 times greater than carbon dioxide $\left(\mathrm{CO}_{2}\right)$ and an atmospheric life of about 12 years [10]. It is a climate change issue, and organic waste is in the contributing stream. Although the conversion of the MSW generated to useful products, in addition to resource recoveries such as bio-energy and compost, will promote the reduction of GHG emissions. That is, the adoption, development and improvement of clean technologies like WtE have the potentials to minimise environmental impacts.

Therefore, the aim of this study is to investigate the potentials of WtE development in developing economies; the scale and point at which it is viable in an efficient MSWM transition program. Also, to emphasise the need for stakeholders in the resource recovery sector, including the government and investors, to elicit their interest in implementing a socio-technical assessment framework that will support sustainable resource recovery programs that can include $\mathrm{WtE}$, in developing economies.

The implementation of the framework can potentially act as a compass on the way forward regarding the development of WtE technology in developing economies.

\section{Methodology}

This study deploys a descriptive analysis of MSW generated in a developing economy, Nigeria. The MSW generated in selected states across the country was analysed to determine the potential WtE, depending on the implementation of an efficient waste management system. The unexplored potentials have been compared to waste generated in developed economies and its conversion to biogas for utilisation as heat energy and electricity. Also, inferential analysis (determination of the cause and effect) of the socio-technical challenges associated with WtE in Nigeria, was investigated. This study evaluates the challenges and opportunities presented by socio-technical systems in the development of $\mathrm{WtE}$ in developing economies, as compared to developed countries.

\section{Geographical background}

The focus of this study is Nigeria, a country located in West Africa, and its coast lies along the Gulf of Guinea in the Atlantic Ocean. It lies within latitudes $4.32^{\circ} \mathrm{N}$ and $14^{\circ} \mathrm{N}$ and longitudes $2.72^{\circ} \mathrm{E}$ and $14.64^{\circ} \mathrm{E}$. It has a land area of $923768 \mathrm{~km}^{2}$ and population growth rate of approximately $2.7 \%$ p.a. in 2015 . The 2006 population census in Nigeria, as reported by the National Population Commission, NPC, was approximately 140.5 million people [11]. However, the World Bank development indicator shows the country to have an estimated 182 million people and annual population growth of $2.6 \%$, in 2015 . The country accounts for approximately $47 \%$ of West Africa's population [12].

The climatic conditions of the country, as described by the National Bureau of Statistics [13], is favourable and varied with the existence of two seasons. They are the dry and rainy season. The wet season is from April to October and the dry season lasts from November through March. The climate is equatorial and semi-equatorial in nature, characterised by high humidity and significant rainfall. The country is made up of 36 states, excluding the Federal Capital Territory (FCT), Abuja.

\section{Overview of MSWM and WtE potentials}

MSWM, in developed and developing economies, directly impacts local and global environmental sustainability. Although a substantial cultural shift in reduce, reuse and recycling (3R) have improved the situation in developed economies like Sweden, Netherlands, United States, Germany, many developing nations are trailing far behind. In developed countries, Tchobanoglous et al. [14] mentioned six functional elements of SWM activities. These are waste generation; waste handling and separation, storage, and processing at the source; collection; separation, processing, and transformation; transfer and transport; and disposal. And in contrast, MSW is handled several numbers of times in most developing countries, and this presents the challenge of closing any mass balance. This action has contributed to the absence of the Directorate culture and fit for purpose technology required to reduce the challenge of WtE generation from MSW in these developing economies.

In their study, Diaz et al. [15] proposed environmental sound technologies for developing countries without mentioning the transitions and socio-technical systems required for implementation. The transition experience of developing economies as it moves through the hierarchy of change in MSWM was unaddressed. MSW technology does not operate in the absence of a socio-technical systems analysis that incorporates environmental strategies, implemented in transitions. Any selected technology has to be adaptable to local conditions, after due considerations, and accepted by the end user. In proposing MSW technologies for any environment, many factors are considered. Borglin et al. [16] mentioned some of the factors for consideration to include; feasibility, ease of use (social acceptance), education requirement, infrastructure needs, economics, a potential for pollution, GHG emissions, land use requirements and technology needs for further development. 
Table 1. Average organic waste generated in ten selected cities of Nigeria.

\begin{tabular}{lllll}
\hline Selected Nigerian capital cities & $\begin{array}{l}\text { Population estimate } \\
(2014)\end{array}$ & $\begin{array}{l}\text { Average waste } \\
\text { generated } \\
(\mathrm{kg} / \text { capita/day })[27]\end{array}$ & $\begin{array}{l}\text { Average organic } \\
\text { fraction of waste } \\
(\%)[27]\end{array}$ & $\begin{array}{l}\text { Average organic } \\
\text { waste generated } \\
(\mathrm{kg} / \text { day })\end{array}$ \\
\hline Lagos & 11112000 & 0.73 & 36 & 2920234 \\
Port-Harcourt & 1700000 & 0.70 & 60 & 714000 \\
Abuja & 950000 & $0.66^{\mathrm{a}}$ & 65 & 407550 \\
Kano & 3500000 & 0.56 & 51 & 999600 \\
Ibadan & 1640000 & $0.51^{\mathrm{a}}$ & 61 & 510204 \\
Kaduna & 936000 & $0.58^{\mathrm{a}}$ & 63 & 342014 \\
Benin City & 1330000 & 0.63 & 54 & 452466 \\
Jos & 1200000 & 0.23 & 57 & 157320 \\
Sokoto & 610000 & 0.28 & 66 & 112728 \\
Ilorin & 954000 & 0.25 & 70 & 166980 \\
\hline
\end{tabular}

${ }^{\mathrm{a}}$ Ogwueleka [24].

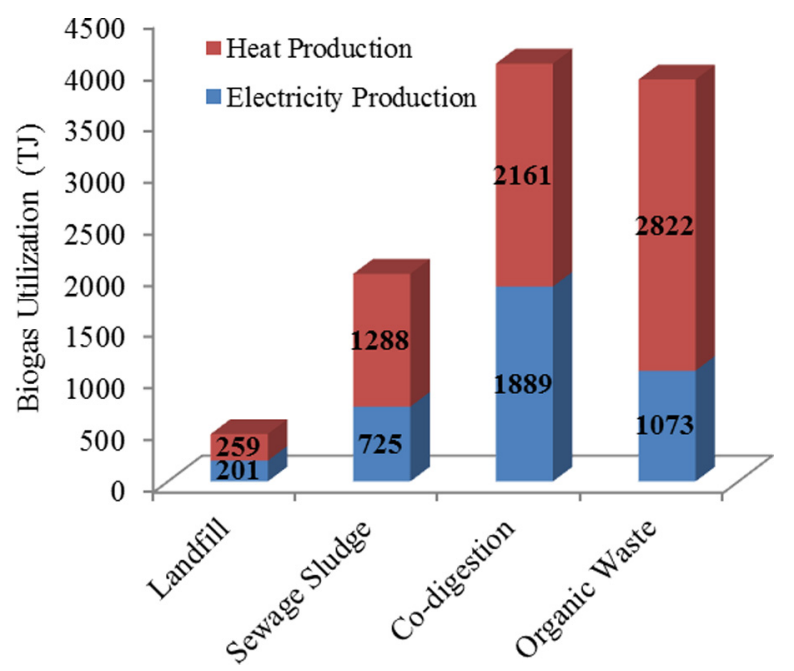

Fig. 1. Utilization of biogas in the Netherlands, 2014. Adapted from [40].

In their contribution to resource recovery from MSW in Nigeria, Abila [17] investigated the potentials of MSW in the energy mix, proposing a management system for energy generation and material recovery. However, this framework had no transition strategy that would enable the implementation of socio-technical parameters. Also, in its investigation of energy and sustainable development in Nigeria, Oyedepo [18] recommended the generation of biogas from livestock and animal husbandry. The feedstock for biogas production transcends livestock and animal husbandry as clearly demonstrated by Biogass Renewables Australia [19], indicating the need to strategically apply socio-technical parameters in transitioning to the use of sustainable technology.

Nigeria is a country that has attempted to implement a WtE project in the past. Previous attempts to set up waste incineration facilities in Lagos, Nigeria, at the cost of US $\$ 30$ million, were unsuccessful [20]. The lack of necessary supplies, skilled personnel, predictive maintenance and external services, have been attributed to the technology implementation drawback [21]. Although advanced WtE can reduce GHG emissions, the technology can only be introduced and evaluated by the net energy efficiency [22]. Without an understanding of the sociotechnical issues and environmental strategies associated with the transitioning of MSWM, achieving a sustainable system would be difficult.

For efficient WtE process incorporation in MSWM, one of the influencing factors is the characterisation of the MSW generated. The characterisation will influence the appropriate technology desired for the WtE process. Organic materials constitute the mainstream of waste generated in most developing economies.

The organic waste stream of MSW in developing countries is well over $50 \%$ [23], and for a country like Nigeria with no formal recycling or resource recovery programs [24], this is a WtE opportunity that is unexplored. In their review of the characterisation of MSW generation in Abuja, Nigeria's capital city, Abur et al. [25] based it on the climatic seasons. The highest percentage of MSW generated was food/putrescible waste. The values were $56 \%$ and $52 \%$ for the wet and dry season, respectively. The average composition of waste in Nigeria is approximately $50-70 \%$ putrescible and 30-50\% non-putrescible [5,6], presenting much resource recovery potentials in composting and biogas renewable energy. Also, Olabode and Lawrence [26] mentioned that $53 \%$ of all goods, packaged in plastics, accounts for approximately $20 \%$ of total waste generated in the country. This waste stream can be recovered through efficient recycling to boost the inherent potentials in resource recovery and $\mathrm{WtE}$.

Table 1 of ten selected Nigerian cities, showing population estimate for 2014, as calculated by the author, consistently applying a $2.74 \%$ population growth rate to the National Population Census figures of 2006 [11], and the average organic fraction of MSW generated daily.

The primary driver for MSW related activities, as identified by Rodic et al. [28], is the resource value. This resource cost could be in the form of $\mathrm{WtE}$, compost or other recovered materials. WtE is the generic term for a process by which energy is generated from waste materials 


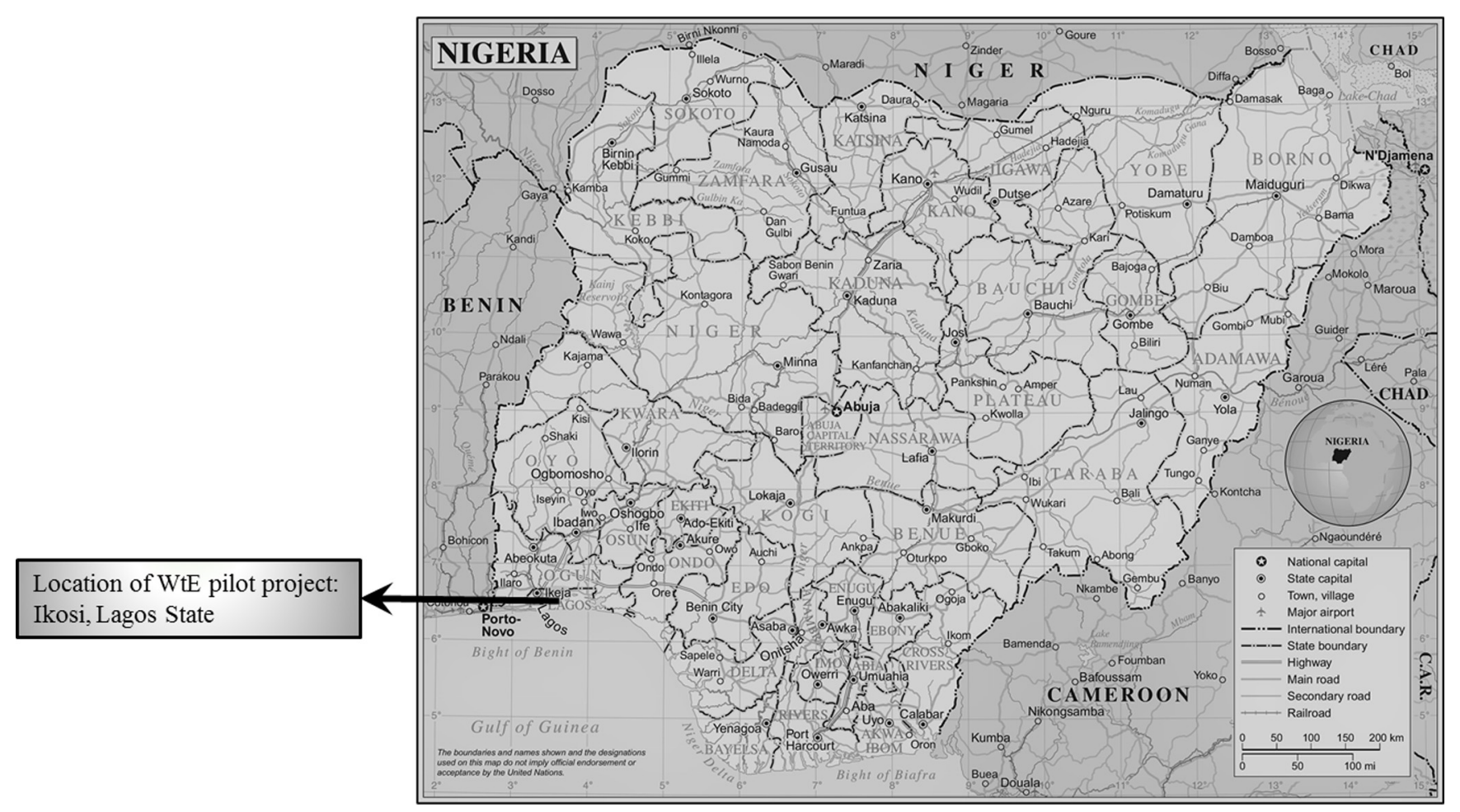

Fig. 2. Map of Nigeria showing the 36 states and the FCT, Abuja [48].

(known as chemical energy) in the form of heat, electricity and fuel, for use in a decentralised energy generation plant [29]. Following this information, it implies that opportunities abound for the generation of WtE and composting in Nigeria, as clearly shown in Table 1.

With reports showing growth of $\$ 19$ billion in 2012 to at least $\$ 29.2$ billion by 2022 [4] in the WtE market, it is no surprise that developing economies like Nepal and China are tapping into this modern technology development [30]. This form of WtE technology is thriving, and according to Schnürer and Jarvis [31], various types of waste can be reduced and stabilised, during digestion to produce renewable and environmentally friendly energy, called biogas. Also, it is arguably a more versatile renewable energy source, in comparison to the wind and solar energy, due to its determinate energy value and non-dependence on geographical locations and seasons [32].

Due to increase in global energy demand, and the need to reduce climate change impacts, the production of renewables has been a hot button issue amongst stakeholders. Energy from biological conversion of organic waste is one form of WtE technology that has drawn so much interest. It is a versatile energy source that can significantly reduce the use of fossil fuels and consequently contribute to energy security, which is a global challenge [33]. In an assessment of the feedstock and relevant biogas technologies feasible in sub-Saharan Africa (SSA), Rupf et al. [34] mentioned the organic fraction of MSW as one of the significant untapped feedstock. By processing this feedstock, Michaels [35] highlighted the benefits as follows: production of renewable, base load energy; reduction of
GHGs; green job creation with reasonable remuneration; superior environmental performance operation; and complementing recycling goals.

\subsection{WtE development in selected countries around the world}

WtE technology has been demonstrated globally with its use in the production of clean, renewable energy and resource recovery from the sustainable management of MSW. The United States has around $75 \mathrm{WtE}$ plants in comparison to Europe's over 400 [36].

In the following section, some WtE technology development around the world is reviewed and compared to its limitations in developing economies.

\subsubsection{Australia}

Bioenergy makes up approximately $8 \%$ of the country's total clean energy. Biogas contributes to about $2 \%$ of the share of total renewable electricity capacity, and a goal of 2413 gigawatt-hours (GWh) for bioelectricity by the year 2020 has been set, with the use of bio-waste and industrial organics as feedstock in anaerobic digesters (AD). This potential could promote the abatement of GHG emission in millions of tonnes in a year [37]. The Clean Energy Finance Corporation estimated that biogas and other WtE projects could potentially contribute $12 \%$ of Australia's national carbon abatement by the year 2020 [38]. 

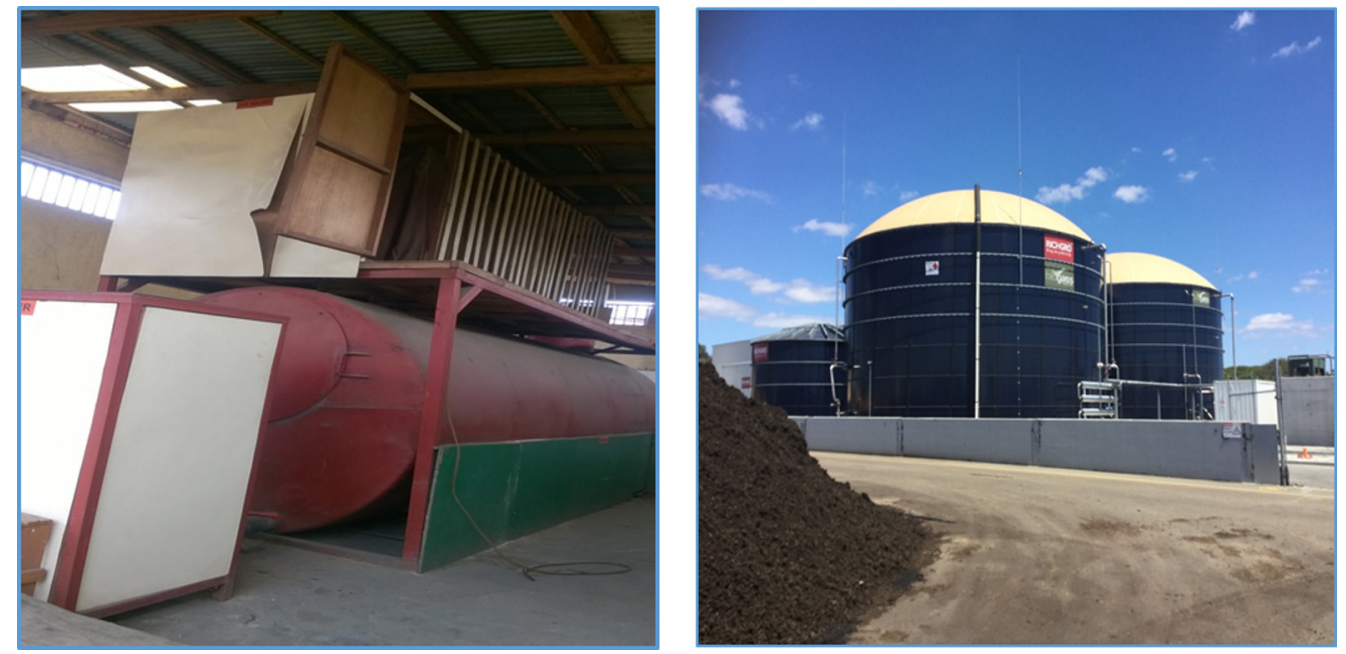

Fig. 3. Pilot anaerobic digester, Ikosi, Nigeria (left), and anaerobic digester, Biogass Renewables Pty Ltd., Perth, Australia (right).

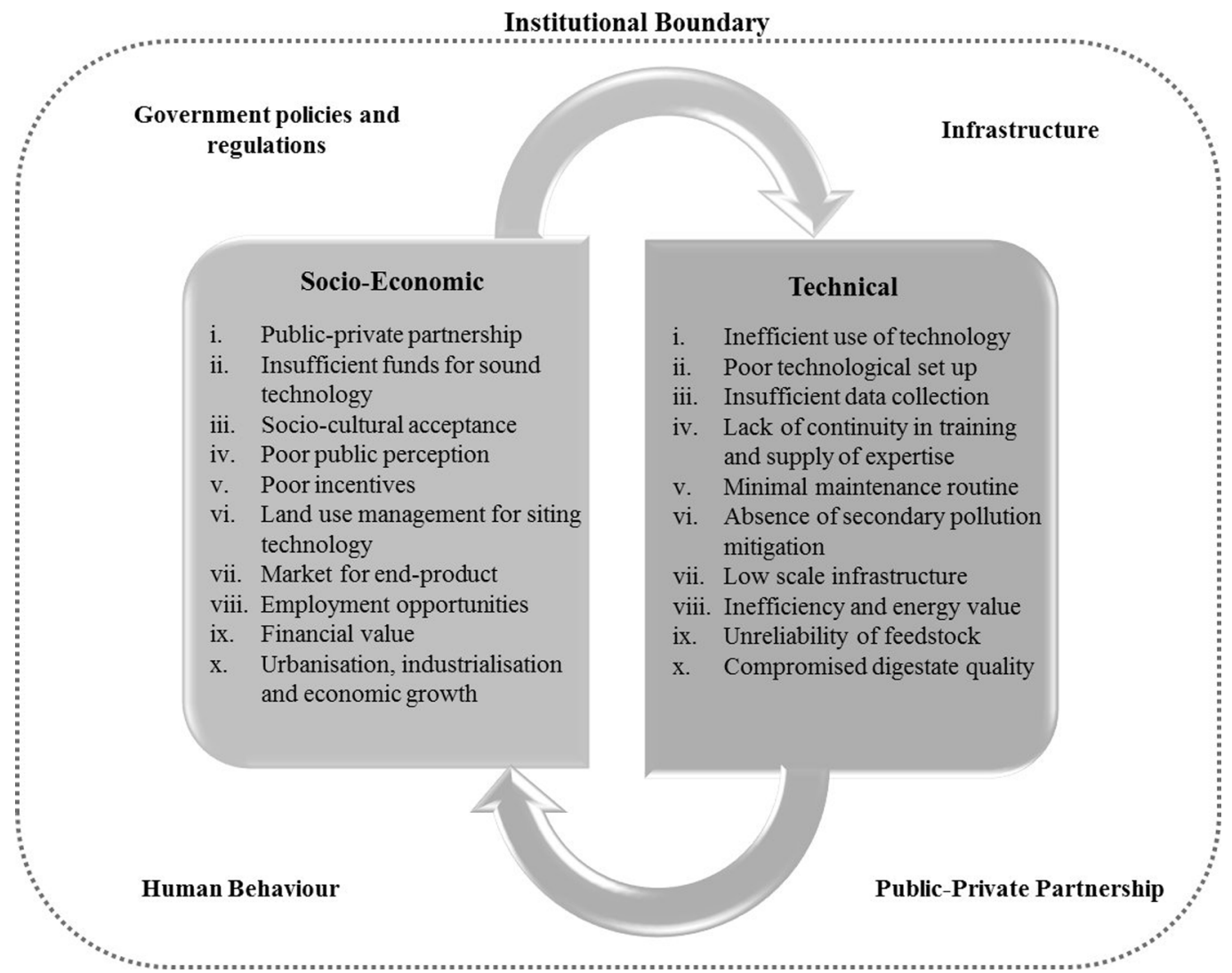

Fig. 4. Socio-technical systems analysis of waste-to-energy in developing economies.

In another development, SUEZ Australia has created smart cells which are Australia's largest generator of biogas used in the production of renewable energy. The developed cells are alternatives to traditional landfills and the energy produced could potentially power over 47000 homes and businesses. In 2014, these smart cells captured over 3 million GJ of biogas, generated over $2 \times 10^{5} \mathrm{MWh}$ of renewable energy, and avoided approximately $3 \times 10^{5}$ $\mathrm{tCO}_{2} \mathrm{E}$ [2]. The country is still on its march towards increased development of renewable energy. In an attempt to support the development of bioenergy, Wilkinson [30] suggests that Australia could learn from the experience of Germany. In Germany, ADs are commonly installed on farms, and the technology has, recently, been exported to Scotland [39].

For a developing economy like Nigeria, where agriculture is the primary industry, this presents a tremendous opportunity. However, it could be far-fetched due to 


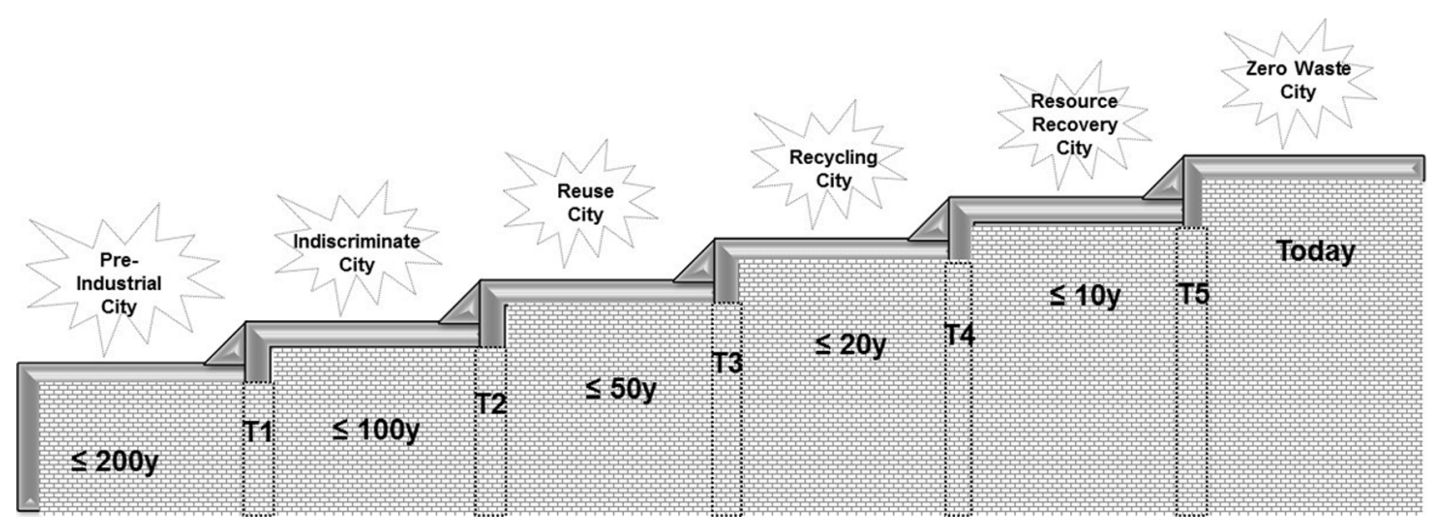

Fig. 5. MSWM transition stages for world economies. $\mathrm{T}=$ transition; $\mathrm{y}=$ years.

socio-technical barriers, which includes; high cost of capital investment, lack of education and awareness, land use act, limited operational expertise. The lack of necessary WtE technology is a dominant issue. There are no operating engineered landfills, bioreactors or large-scale ADs for the production of biogas. Therefore, resources that could potentially be harnessed and recovered for WtE are untapped through indiscriminate disposal in dump sites, which consequently impacts negatively on the environment.

\subsubsection{Netherlands}

Biogas contributed 6.5 PJ to the renewable energy of the Netherlands in 2014. Figure 1 shows other forms of biogas utilisation sources.

Also, the world's largest treatment centre for urban waste is now operational in Amsterdam. The installation of sewage treatment plant next to an expanded WtE plant for solid waste in the city has demonstrated many benefits such as; energy recovery from the sewage sludge; reduction in environmental impact; and reduction in the cost of sludge transportation for disposal [41].

In Nigeria, the situation is contrary as there is no working sewage treatment plant in any of the major cities or rural areas [42]. Therefore, the opportunities and advantages presented by this resource are underutilised. Even so, this calls for concern when the Millennium Development Goals target \#.7, "Ensure Environmental Sustainability" is considered [43]. Also, the energy value from MSW in Nigeria is comparatively insignificant, as estimated by Sambo [44].

\subsubsection{China}

China is building the largest WtE plant in the world, and this project is due for completion by the year, 2020. It is expected to turn a third of Shenzhen's trash into energy daily. The incinerator is one of the 300 plants proposed for construction by the Chinese government [45]. With $17 \%$ of its MSW processed in WtE facilities, China seems to be ahead of the United States, who has only about $8 \%$ of its waste generated destined for a WtE facility, despite generating 387 million tonnes of waste annually [46]. Also, the Chinese government provides a credit of about $\$ 30$ per
MWh of electricity generated using WtE. Besides, the government's 11th Five-Year Plan (2006-2011) showed a conventional construction of many WtE facilities across the country [47].

In comparison to Nigeria, there are no strategic plans for the development of WtE. This lack of foresight has in no small way, impacted the socio-technical parameters engendered in the development of WtE technology, thereby limiting its appreciation in the country [27].

\section{Discussion}

An assessment of the socio-technical system analysis of WtE in developing economies was investigated, using a locally designed pilot project located in Lagos, Nigeria, as a case study. The approximate location of the project, on the Nigerian map, is represented in Figure 2. The pilot scale project is an $\mathrm{AD}$, sited at the end of a fruit market, for proximity to feedstock. The feedstocks were pineapple and watermelon. The size is $26 \mathrm{~m}^{3}$ and a residence time of 21 days. The biogas from the digester serves as fuel for a $10 \mathrm{kVA}$ generating plant, proposed to power street lightings in the market. In comparing the residence time of 21 days to the $2-3$ days' residence time in the case of the CONPOREC accelerated digester operated by SUEZ, Western Australia, the need for technology awareness in developing economies is undeniable.

The technological set-up was low scale and poor public perception due to the unsuccessful completion of the pilot period. Also, the absence of data registry for the operations is a limitation to its efficiency, value and acceptance. Figure 3 shows the pilot scale plant at Ikosi Market, and the $\mathrm{AD}$ in Australia, operated by Biogass Renewables Pty Ltd. The AD run by Biogass receives 30-50 tonnes of food waste daily, and this is processed to generate over $3000 \mathrm{~m}^{3}$ of biogas at $65 \%$ methane $\left(\mathrm{CH}_{4}\right)$, producing approximately $290 \mathrm{kWh} /$ day. In contrast to the pilot scale project in Nigeria, no record of data collection. This limitation hinders purposeful and sustainable operations.

In summary, the socio-technical system analysis that influences $\mathrm{WtE}$ projects in developing economies, including the discussed pilot scale project at Ikosi market, is presented in Figure 4. 
Also, Figure 5 shows a theoretical framework model to explain the transition theory and its strategies in effective MSWM. This transition is an interacting systems transformation that provides perspicacity and structure to support an incremental or fundamental change to a situation, system or institution.

The desired socio-technical transition in MSWM can be approached in stages as shown in Figure 5. The preindustrial and indiscriminate stage is the littering and open burning of garbage. This method of waste management is still very much in practice in most developing countries, including Nigeria. With increasing awareness of the desirable waste strategies of reduce, reuse and recycle (3R), many cities in developing economies are gradually adopting the practice, even though the progress is slow. According to Awopetu et al. [49], being aware of the fact that the 3R principle supports MSWM, this is not sufficient to generate beneficial outcomes without proper education, demonstration and encouraging government policies. The resource recovery cities are mostly found in the developed economies, as shown in Figure 1, with a target of achieving a zero waste city. As investigated by Zaman and Lehmann [50], zero waste index performance has been carried out in some cities like Adelaide, Stockholm and San Francisco. San Francisco, as mentioned by Eberlein [51] and Sullivan [52] is already $78 \%$ of the way to zero waste city, with 2020 set as a target to achieve it [53].

Therefore, it is imperative for governments and relevant institutions to identify and establish their MSWM systems in the transition model. This action will ensure the application of the related socio-technical parameters in evaluating and implementing the appropriate WtE technology.

\section{Recommendations}

The challenges of WtE development often result from several interacting systems and market failures. This challenge cannot be over-emphasised, owing to constraints in the socio-technical analysis of its successful implementation in developing economies. This limitation, consequently, is a drawback for equitable, sustainable development [54], and resource recovery from WtE.

Therefore, a need for energy policy mix that is primarily driven by the government to reduce the avalanche of a continued waste of resources is required. This requirement implies a combination of a policy instrument that is socio-economically driven, technology push and environmentally considered. It will involve profound but enterprising changes to the various government institutions who are stakeholders in the resource recovery industry. However, an understanding of the different policy instruments and the consistency of this mix concerning its influence on cultural, political, organisational and moral ethics of the population is necessary for the promotion of resource recovery, including WtE. Besides, a historical assessment framework of orientation, which will examine the emergence of resource recovery through $\mathrm{WtE}$ in the economy, should be implemented. The result will inform significantly the socio-technical transition desired for a WtE process, and the development of MSW sustainability criteria in Nigeria and other developing economies.

Below are some recommendations for this study:

- Energy targets: this is an area where many developing economies are lacking, especially Nigeria. There are no known set goals regarding the WtE policy that would promote the reduction of $\mathrm{CO}_{2}$ and $\mathrm{CH}_{4}$, which are climate change impacting GHGs;

- Strategic policies: most of the materials exported to the country are packaged in almost non-biodegradable materials, especially polyethene, expressed as $\mathrm{C}_{n} \mathrm{H}_{2 n}$, as this takes a long period to degrade under certain conditions. This action presents the government an opportunity to establish strategic policies that will ensure packaging is manufactured only from materials that allow reuse or recycling. Consequently, this will promote the use of socially appropriate methods for $\mathrm{WtE}$ technologies. Also, the government should promote technological training of locals to embrace and apply current trends in MSWM towards environmental sustainability;

- MSW inventory: the government should ensure an MSW data registry in all local councils. This data will include waste composition, tonnages of the different waste stream, its origin, process and destination. Such database will help identify precinct waste generation and promote efficient management;

- Public private partnership: more sustainable MSW solutions require a public-private partnership, and this should be encouraged by the government. In other words, an enabling environment for investors (local and international) to participate in MSWM through subsidies and policies that will not stifle participation, but with clear and shared objectives. Such partnership will encourage personnel training, capacity building, and awareness creation in every aspect of sustainable MSWM and WtE;

- Transition systems: stakeholders should recognise that WtE development occurs in a transition system with efficient MSWM. Importing off the shelf technology to address MSW issues that require social and cultural interventions should be eliminated. Therefore, transparency amongst the government and public-private cooperation can elicit valuable interest that would eventually lead to the implementation of better projects; - Awareness campaign: behaviour change could be challenging, but it is imperative for the government to consider this social impact without compromise. A reward and incentive model mixed with regular community meetings should be encouraged. Also, promoting the production and consumption of products derived from recycled and recyclable materials could serve as the tonic for the behavioural change that will enhance appreciation for WtE technology;

- Decentralised approach: a decentralised approach is required to address structural factors, demography and elite discretion. Collaboration between local councils, energy companies and local farmers can encourage WtE technology in the communities; 
- Access to soft loans: barriers to financial investments in WtE technology in developing economies should elicit support from the government. Access to soft loans, infrastructure grants and other financial incentives $[30,55,56]$, should be encouraged by the government to ensure sustainability and progress in the MSWM transition process;

- Interdisciplinary cooperation: interdisciplinary and trans-disciplinary cooperation can be promoted by the policies to foster sustainable resource recovery such as WtE. This collaboration will bridge the existing gaps and reconcile the inconsistencies that could arise out of the interactions between the socio-technical and environmental considerations, for an effective WtE program in developing economies. This strategy is necessary because not all renewable projects are in line with sustainable requirements [57].

\section{Conclusion}

A deep lying issue with the institutions that regulate environmental policies in the society is a minimal understanding of socio-technical transitions that could impact, profoundly, WtE projects.

One of the pathways to the socio-technical promotion of $\mathrm{WtE}$ is an appreciation of the matrix that connects disciplinary perspectives to the understanding of MSWM by individuals, communities and the society as a whole. From the social viewpoint, an appraisal of the awareness and understanding of the traditional 3R by the population is necessary. This assessment will result in improving existing MSWM framework and implementation strategies. This evaluation could be done periodically to check the level of effort and following response from the population.

Also, the historical background and boundary identification of waste management transitions will inform the technologist and the engineers in the design of an appropriate $\mathrm{WtE}$ technology that is fit for purpose. However, the design, development and application of this technology will be limited until environmental concerns become a prominent public and political discussion, taking into consideration the following influencing parameters: social, cultural, ethical, moral, organisational, political, economic and technical hardware.

WtE is an appropriate solution that could be integrated into the energy supply mix for a developing economy, considering the widespread perception that, energy is a national security issue [58]. Also, the characteristics and amount of waste generated present an excellent platform for a high consideration of the technology. Table 1 gave an indication of the opportunities in the conversion of $\mathrm{WtE}$ that is underutilised in Nigeria.

The point in the transition at which WtE becomes relevant is in the resource recovery stage. Although it is addressed on a case by case basis due to the socio-cultural dynamics, economic and industrial structure, waste management regulations and environmental factors that influence the various stages in the transition. However, the fundamentals necessary to reach a point of consideration is an efficient waste management process, implemented and sustained throughout the transition. Also, treating as a socio-technical regime [58] will increase the learning and understanding of the processes involved in the transformation and realisation of $\mathrm{WtE}$ projects in developing economies. Whatever socio-technical regime adopted for any MSWM situation, it has to be socially acceptable [59], sustainable and affordable. A promotion of this principle would give waste a second life.

\section{References}

1. ISWA, Globalization and waste management, International Solid Waste Association, Austria, July 2012

2. SUEZ, SUEZ Australia \& New Zealand corporate video, 10 January 2017

3. R. RenoSam, The most efficient waste management system in Europe, Waste-to-energy in Denmark, Technical report, 2006

4. TAQA, Waste-to-energy, TAQAWORLD, 2013

5. S. Ojoawo, O. Agbede, A. Sangodoyin, On the physical composition of solid wastes in selected dumpsites of Ogbomosoland, South-Western Nigeria, J. Water Resour. Prot. 3, 661 (2011)

6. P.C. Osuocha, Integrated development for water supply and sanitation: improving refuse management in urban Nigeria, in Presented at the Water, Engineering and Development Centre, Ethiopia (1999)

7. S. Sandu, L. Jaques, M. Bradshaw, L. Carson, A. Budd, M. Huleatt et al., Australian Energy Resource Assessment, 2010

8. J. Gustavsson, C. Cederberg, U. Sonesson, R. Van Otterdijk, A. Meybeck, Global food losses and food waste, Food and Agriculture Organization of the United Nations, Rome, 2011

9. A. Butu, S. Mshelia, Municipal solid waste disposal and environmental issues in Kano metropolis, Nigeria, Br. J. Environ. Sci. 2, 1-16 (2014)

10. G. McCarthy, Standards of Performance for Municipal Solid Waste Landfills, in USEPA (2015), Vol. 80

11. N.P. Commission, National population census (National Population Commission, Abuja, Nigeria, 2006)

12. EuropeAid, Feasibility study of the waste to energy (WtE) project of the Ogun State Government, European Union, Abuja, 2013

13. N.B. Statistics, Annual Abstract of Statistic, in N. B. o. Statistics (NBS, Nigeria, 2009)

14. G. Tchobanoglous, H. Theisen, S. Vigil, Integrated Solid Waste Management: Engineering Principles and Management Issues (McGraw-Hill Science/Engineering/Math, New York, NY, 1993)

15. L.F. Diaz, G.M. Savage, L.L. Eggerth, Solid Waste Management (UNEP/Earthprint, London, 2005), Vol. 1

16. S. Borglin, J. Shore, H. Worden, R. Jain, An overview of the sustainability of solid waste management at military installations, Int. J. Environ. Technol. Manag. 13, 51-83 (2010)

17. N. Abila, Managing municipal wastes for energy generation in Nigeria, Renew. Sustain. Energy Rev. 37, 182-190, 9 (2014)

18. S.O. Oyedepo, Towards achieving energy for sustainable development in Nigeria, Renew. Sustain. Energy Rev. 34, 255-272, 6 (2014)

19. R.P.L. Biogass, Anaerobic Digestion in Australia - Biogass Renewables, 26 December 2016 
20. M. Medina, Waste picker cooperatives in developing countries, in Membership-Based Organizations of the Poor, edited by M. Chen et al. (Routledge, London, 2007), pp. $105-121$

21. W. Bank (ed.), Municipal solid waste incineration: World Bank technical guidance report, The World Bank, Washington, DC, 1999

22. Y. Li, W. Teng, W. Wang, T. Yang, R. Li, Waste-to-energy in China: status and prospects, 2015

23. A.J. McMichael, The urban environment and health in a world of increasing globalization: issues for developing countries, Bull. World Health Organ. 78, 1117-1126 (2000)

24. T. Ogwueleka, Municipal solid waste characteristics and management in Nigeria, J. Environ. Health Sci. Eng. 6, 173$180(2009)$

25. T. Abur, E.E. Oguche, B. Gideon Ayuba Duvuna, Characterization of municipal solid waste in the Federal Capital, Abuja, Nigeria, Glob. J. Sci. Front. Res. 14, 1-6 (2014)

26. A.D. Olabode, A. Lawrence, Environmental impact of indiscriminate waste disposal on river channel in part of Akoko-region, Ondo state, Nigeria, Int. J. Innov. Scient. Res. 5, 162-168 (2014)

27. Y.S. Mohammed, M.W. Mustafa, N. Bashir, M.A. Ogundola, U. Umar, Sustainable potential of bioenergy resources for distributed power generation development in Nigeria, Renew. Sustain. Energy Rev. 34, 361-370, 6 (2014)

28. L. Rodic, A. Scheinberg, D.C. Wilson, Comparing solid waste management in the world's cities, in ISWA World Congress (2010)

29. S. Wood, M. Fanning, M. Venn, K. Whiting, Review of stateof-the-art waste-to-energy technologies, Stage Two, Case Studies, London, UK, 2013, pp. 9-30

30. K.G. Wilkinson, A comparison of the drivers influencing adoption of on-farm anaerobic digestion in Germany and Australia, Biomass Bioenergy 35, 1613-1622 (2011)

31. A. Schnürer, A. Jarvis, Microbiological Handbook for Biogas Plants: RAPPORT U2009:03, 2009 (10 November 2016)

32. M. Pöschl, S. Ward, P. Owende, Evaluation of energy efficiency of various biogas production and utilization pathways, Appl. Energy 87, 3305-3321, 11 (2010)

33. L.A. Pellegrini, G. De Guido, S. Consonni, G. Bortoluzzi, M. Gatti, From biogas to biomethane: how the biogas source influences the purification costs, Chem. Eng. Trans. 43, 409-414 (2015)

34. G.V. Rupf, P.A. Bahri, K. de Boer, M.P. McHenry, Broadening the potential of biogas in Sub-Saharan Africa: an assessment of feasible technologies and feedstocks, Renew. Sustain. Energy Rev. 61, 556-571 (2016)

35. T. Michaels, The 2014 ERC Directory of waste-to-energy facilities, Energy Recovery Council, 2014

36. J. Salvatore, World energy perspective: cost of energy technologies, Bloomberg New Energy Finance, 2013

37. B. McCabe, Country report, Australia, IEA Bioenergy, 2015

38. M. Ritchie, Report: state of waste 2016 - current and future Australian trends, 2016 (19 December 2016)

39. B. Messenger, Cogeneration plant exports $500 \mathrm{~kW}$ energy from waste to grid, 2016 (19 December 2016)
40. M. Dumont, Country report NL, Netherlands Enterprise Agency, Berlin, Germany, 2015

41. T.M. McCarthy, M. Van Berlo, A symbiotic solution (Waste Management World, 2007)

42. A. Abutu, No sewage treatment plant in Nigeria, in Daily Trust, Nigeria (2014)

43. U. Nations, Sustainable development goals - United Nations, 2015 (5 July 2016)

44. A.S. Sambo, Strategic developments in renewable energy in Nigeria (International Association for Energy Economics, 2009), Vol. 16, pp. 15-19

45. B. Crew, China is building the largest waste-to-energy plant in the world, Science Alert, 2016

46. N.J. Themelis, C. Mussche, Municipal solid waste management and waste-to-energy in the United States, China and Japan, in Second International Academic Symposium on Enhanced Landfill Mining, Houthalen-Helchteren (2013)

47. N. Themelis, Z. Zhang, WTE in China (Waste Management World, 2010) (19 December 2016)

48. U. Nations, Atlas of the World, 18 December 2014

49. M. Awopetu, A. Coker, R. Awopetu, S. Awopetu, A. Ajonye, O. Awopetu, Residents' knowledge of waste reduction, reusing and recycling in Makurdi metropolis, Nigeria, WIT Trans. Ecol. Environ. 163, 51-59 (2012)

50. A.U. Zaman, S. Lehmann, The zero waste index: a performance measurement tool for waste management systems in a 'zero waste city', J. Clean. Prod. 50, 123-132 (2013)

51. S. Eberlein, Where No City Has Gone Before: San Francisco Will Be World's First Zero-Waste Town by 2020, 2012, retrieved from AlterNet: http://www.alternet.org/story/ 155039/where_no_city_has_gone_before\%3A_san_fran cisco_will_be_world's_first_zero-waste_town_by_2020

52. D. Sullivan, Zero waste on San Francisco's horizon, Biocycle 52, 28 (2011)

53. M. Diamond, San Francisco: sustainability and the new energy horizon in a model city, Urban Sustainability Programs: Case Studies, 2013, p. 132

54. P. Kumar, G. Bhowmick, Solid waste management - the obvious answer, in Environment Management with Indian Experience (APH Publishing Corporation, New Delhi, 1998), pp. $173-176$

55. A.L. Bufoni, L.B. Oliveira, L.P. Rosa, The declared barriers of the large developing countries waste management projects: the STAR model, Waste Manag. 52, 326-338 (2016)

56. C.R. Lohri, E.J. Camenzind, C. Zurbrügg, Financial sustainability in municipal solid waste management - costs and revenues in Bahir Dar, Ethiopia, Waste Manag. 34, 542-552 (2014)

57. H. Armstrong, Sustainable energy landscapes: designing, planning and development, Landsc. Res. 40, 510-512 (2015)

58. P. Andrews-Speed, Applying institutional theory to the lowcarbon energy transition, Energy Res. Social Sci. 13, 216-225 (2016)

59. E. Den Boer, J. den Boer, J. Jager, Waste management planning and optimisation (LCA IWM, Stuttgart, Germany, 2005)

Cite this article as: Hope O. Iyamu, Martin Anda, Goen Ho, Socio-technical systems analysis of waste to energy from municipal solid waste in developing economies: a case for Nigeria, Renew. Energy Environ. Sustain. 2, 21 (2017) 